\title{
Mutant Cbl proteins as oncogenic drivers in myeloproliferative disorders
}

\author{
Mayumi Naramura1,2, Scott Nadeau1,2, Bhopal Mohapatra1,3, Gulzar Ahmad ${ }^{1}$, \\ Chandrani Mukhopadhyay ${ }^{1}$, Martin Sattler ${ }^{5}$, Srikumar M Raja ${ }^{1}$, Amarnath \\ Natarajan ${ }^{1,4}$, Vimla Band ${ }^{1,2}$, Hamid Band ${ }^{1,2,3}$ \\ ${ }^{1}$ Eppley Institute for Research in Cancer and Allied Diseases, University of Nebraska Medical Center, Omaha, NE \\ 2 Department of Genetics, Cell Biology and Anatomy, College of Medicine, University of Nebraska Medical Center, Omaha, NE \\ ${ }^{3}$ Department of Biochemistry \& Molecular Biology, College of Medicine, University of Nebraska Medical Center, Omaha, NE \\ ${ }^{4}$ Department of Pharmaceutical Sciences, College of Pharmacy, University of Nebraska Medical Center, Omaha, NE \\ ${ }^{5}$ Dana Farber Cancer Institute, Harvard Medical School, Boston, MA \\ Correspondence to: Mayumi Naramura, email: mnaramura@unmc.edu
}

Hamid Band, email: hband@unmc.edu

Keywords: Cbl, E3 ubiquitin ligase, leukemia, protein tyrosine kinase, signal transduction

Received: March 7, 2011

Accepted: March 20, 2011 ,

Published: March 20, 2011

Copyright: (c) Naramura et al. This is an open-access article distributed under the terms of the Creative Commons Attribution License, which permits unrestricted use, distribution, and reproduction in any medium, provided the original author and source are credited.

\section{ABSTRACT:}

\begin{abstract}
Casitas B-lineage lymphoma $(\mathrm{Cbl})$ family proteins are evolutionarily-conserved attenuators of protein tyrosine kinase (PTK) signaling. Biochemical analyses over the past two decades have firmly established that the negative regulatory functions of $\mathrm{Cbl}$ proteins are mediated through their ability to facilitate ubiquitination and thus promote degradation of PTKs. As aberrant activation of PTKs is frequently associated with oncogenesis, it has long been postulated that loss of normal $\mathrm{Cbl}$ functions may lead to unregulated activation of PTKs and cellular transformation. In the last few years, mutations in the $C B L$ gene have been identified in a subset of human patients with myeloid malignancies. Here we discuss insights gained from the analyses of Cbl mutants both in human patients and in animal models and propose potential mechanisms of oncogenesis through this pathway.
\end{abstract}

\section{INTRODUCTION}

While hematological malignancies represent less than $10 \%$ of all cancer cases in the United States [1], studies into their pathogenesis have led to critical insights into the molecular mechanisms of cancer initiation and progression including fundamental paradigm shifts such as the stem cell hypothesis of cancer [2]. Hematological malignancies have also been at the forefront of studies that led to the development of molecularly targeted therapeutics [3]. Thus, identification of a novel driver of oncogenesis in hematological neoplasms is likely to shed new light on mechanisms of oncogenesis relevant to diverse types of cancer. It is in this context that recent identification of mutations in $C B L$ in a small but significant proportion of patients with myeloid malignancies provides an important milestone. In this article, we review the basic functions of $\mathrm{Cbl}$ family proteins, survey their mutations in human patients and animal models that manifest as myeloproliferative/myelodysplastic syndromes and propose potential mechanisms of oncogenesis and possible strategies to treat patients with $C B L$ mutations.

\section{CBL FAMILY PROTEINS}

Members of the Casitas B-lineage lymphoma (Cbl) protein family are evolutionarily-conserved multi-domain regulators of signal transduction (reviewed in [4-6]). In mammals, this family includes $\mathrm{Cbl}$ (also known as c-Cbl), Cbl-b and Cbl-c (also known as Cbl-3 or Cbl-SL [7]). Extensive biochemical studies have demonstrated that they act primarily as attenuators of cellular signals by functioning as E3 ubiquitin ligases directed towards protein tyrosine kinase (PTK) pathways [8-10]. The $\mathrm{N}$-terminal regions of all $\mathrm{Cbl}$ family members are highly conserved; these include the tyrosine kinase binding (TKB) domain, the RING finger (RF) domain and the short linker region between these two domains. Structural analyses have shown that the TKB domain is composed of a four-helical bundle, a calcium-binding EF hand and a variant $\mathrm{SH} 2$ domain [11]; together, these domains constitute a relatively unique platform that mediates 
specific binding to cognate phosphotyrosine-containing motifs almost exclusively found in activated PTKs. The RING finger domain and the linker region together mediates binding to E2 ubiquitin-conjugating enzymes and both of these motifs are essential for the E3 ubiquitin ligase activity of $\mathrm{Cbl}$ proteins [12].

The carboxyl regions of $\mathrm{Cbl}$ family members are more divergent; while Cbl-c possesses a relatively short region carboxyl to the $\mathrm{RF}$ domain, $\mathrm{Cbl}$ and $\mathrm{Cbl-b}$ contain multiple protein-protein interactions motifs including: proline-rich regions that bind to $\mathrm{SH} 3$ domains of a number of signaling proteins such as Src family kinases and the Grb2 adaptor protein; tyrosine residues that become phosphorylated upon cellular activation and interact with key signaling mediators such as the Vav family guanine nucleotide exchange factors, the $\mathrm{p} 85$ regulatory subunit of phosphatidylinositol 3-kinase (PI3K) and Crk family adaptors; and leucine zipper/ubiquitin-associated (LZ/ UBA) domain that is proposed to be involved in homoand hetero-dimerization of $\mathrm{Cbl}$ proteins.

Conclusions based on biochemical evidence that $\mathrm{Cbl}$ proteins function as attenuators of mammalian PTKs have been validated by animal models that demonstrated enhanced biological responses when $\mathrm{Cbl}$ family members are genetically ablated. For example, $C b l$-null mice show increased cellularity in the hematopoietic organs [13-15] whereas Cblb-null mice exhibit hyper-responsiveness to immunological insults leading to autoimmunity $[16,17]$; this phenotype was further augmented to a fulminant inflammatory disease when $\mathrm{Cbl}$ and Cbl-b were concurrently deleted in the T cell compartment [18]. Given that $\mathrm{Cbl}$ proteins associate with a variety of growth factor receptors, their negative regulatory roles towards PTKs engendered an expectation that $\mathrm{Cbl}$ proteins may function as tumor suppressors and that their mutations and/or deletions could contribute as driving or accessory oncogenic mechanisms. This hypothesis was further supported by the historical background that $\mathrm{Cbl}$ was originally identified as a cellular homolog of a murine viral oncogene ( $\mathrm{v}-\mathrm{Cbl})$; this fibroblast-transforming gene was a fusion of the Cbl TKB domain with the viral gag sequences [19]. Combined with studies on the Cbl linker/ $\mathrm{RF}$ domain mutants including a pre-B cell line-derived $70 \mathrm{Z} \mathrm{Cbl}$ as well as various engineered mutants [20], these data altogether indicated that the linker/RF domains were critical for a potential tumor suppressor role of $\mathrm{Cbl}$ proteins. Yet, a direct role of $\mathrm{Cbl}$ proteins in human cancers remained elusive until recently.

\section{MUTANT CBL AND MYELOID MALIGNANCIES}

In 2007, two groups simultaneously identified $C B L$ mutations in acute myeloid leukemia (AML) patient samples [21, 22]. Since then, a number of independent studies confirmed and extended these observations and a consensus has gradually emerged on the nature of $C B L$ mutations and their clinical manifestations [23-32].

\section{TKB domain RING Pro-rich $\quad Y Y Y$ LZ/UBA}
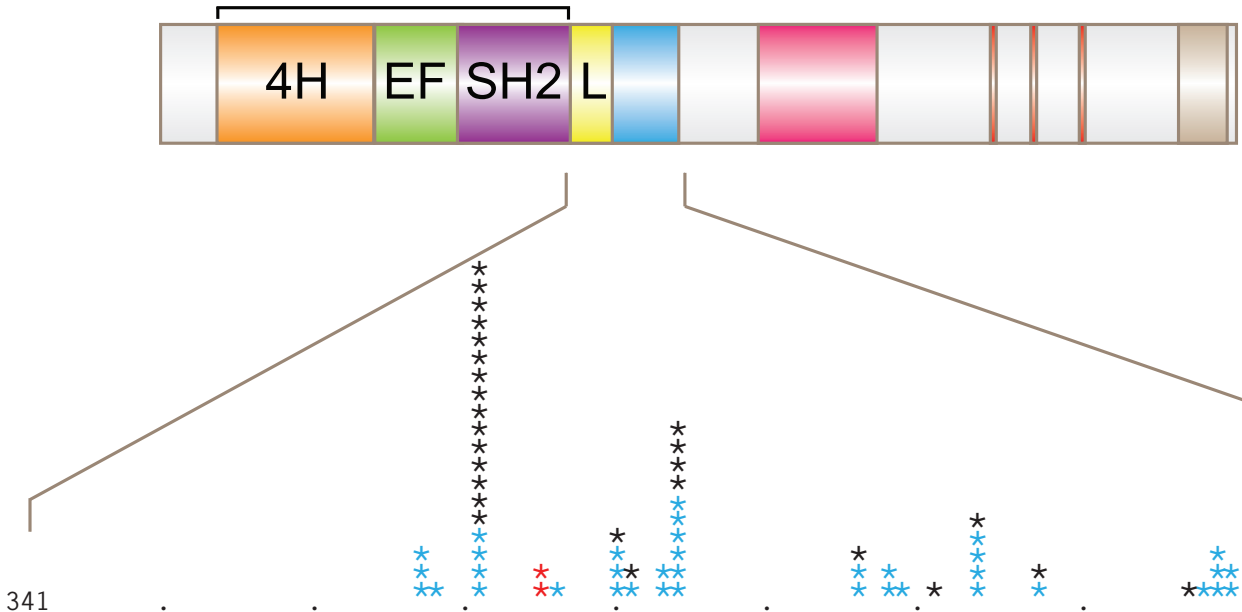

* $\mathrm{AML}$ * MDS * JMML 作 DGRNQNPDLTGLCEPTPQDHI KVTQEQYELYCEMGSTFQLCKICAENDKDVKIEPCGHLMCTSCLTSWQ-ESEG - - QGCPFCRCEIKGTEPIVVDPFDP - R DGQAYNPDLSSAVQSPTEDHITVTQEQYELYCEMGSTFQLCKICAENDKDIRIEPCGHLLCTPCLTSWQVDSEG - - QGCPFCRAEIKGTEQIVVDAFDP - R

NGRDQD INLSKLMDVPQADRVQVTSEQYELYCEMGTTFELCKICDDNEKN IKI EPCGHLLCAKCLANWQ - DSDGGGNTCPFCRYEIKGTNRV I IDRFKPTP
DGRSYNPDLTGLCEPTPHDHI I VTQEQYELYCEMGSTFQLCKICAENDKDVKIEPCGHLMCTSCLTAWQ- ESDG- - QGCPFCRCEIKGTEPI I VDPFDP-R

Cb1 (mouse)

Cbl $(f l y)$

Cbl (worm) Cb1-b (human) DGRSYNPDLTGLCEPTPHDHIKVTQEQYELYCEMGSTFQLCKICAENDKDVKIEPCGHLMCTSCLTAWQ-ESDG- - QGCPFCRCEIKGTEPI IVDPFDP-R Cb1-c (human) DGKTHNPDLTELGQAEPQQRIHVSEEQLQLYWAMDSTFELCKICAESNKDVKIEPCGHLLCSCCLAAWQ -HSDS - - QTCPFCRCEIKGWEAVSIYQFHG - Q

Schematic representation of mammalian Cbl, alignments of amino acid sequences for various Cbl family proteins, and positions of clinically-identified $\boldsymbol{C B L}$ missense mutations. Mutations were compiled from published papers. TKB, tyrosine kinasebinding domain; 4H, four-helix bundle; EF, EF hand; SH2, Src-homology domain 2; L, linker; RING, "really interesting new gene" finger domain; Y, tyrosine residue; LZ/UBA, leucine zipper/ubiquitin associated domain. 
First, $C B L$ mutations are most frequently observed in a distinct group of myeloid disorders, namely myelodysplastic syndromes-myeloproliferative neoplasms (MDS/MPN); this subgroup of hematological malignancies includes the chronic myelomonocytic leukemia (CMML), atypical chronic myeloid leukemia (aCML) and juvenile myelomonocytic leukemia (JMML). Notably, these malignancies are often associated with hallmark genetic aberrancies that culminate in activation of the Ras-MAPK signaling pathway [33, 34]. For example, the activating mutations of PTPN11, NRAS and $K R A S$, and loss of Ras GTPase-activating protein gene $N F 1$ together account for approximately $75 \%$ cases of JMML. CBL mutations are now known to account for roughly half of the remaining cases. Among CMML patients, $R A S$ mutations are reported in 20 to $60 \%$ of the cases.

Second, most $C B L$ mutations are missense mutations or small deletions around the linker region and within the RF domain. Where tested, these mutations have been shown to abrogate the E3 ubiquitin ligase activity of $\mathrm{Cbl}$ $[21,26,28]$. Complete $C B L$ gene deletion, truncation, or mutations outside of the linker/RING finger regions are rare. These characteristics strongly suggest that the expression of mutant $\mathrm{Cbl}$ proteins confers growth and/or survival advantages over cells expressing wild-type $\mathrm{Cbl}$ or even those that have lost $\mathrm{Cbl}$ expression.

Third, a remarkable feature of patients with $\mathrm{Cbl}$ mutations is that the wild-type $C B L$ allele is frequently lost in leukemic clones and is replaced with the mutant allele by acquired uniparental isodisomy (aUPD). Although mutations in $C B L B$ and $C B L C$ have also been reported, they appear to be rare compared to $C B L$ mutations. In this regard, deletion of the wild-type $C B L$ allele and acquisition of a second mutant allele may represent a defining oncogenic event; this hypothesis is most clearly supported by observations in JMML patients, where $C B L$ mutations are often inherited as hemizygous germline mutations [32]. Apparently, a mutant $\mathrm{Cbl}$ protein encoded by a hemizygous $C B L$ mutation is not sufficient to counter the function of $\mathrm{Cbl}$ family proteins encoded by the remaining wild-type $C B L$ allele plus two wild-type $C B L B$ alleles. This is further backed by experimental data that mutant $\mathrm{Cbl}$ proteins confer far more growth advantage on a $C b l$-deficient background compared to a $C b l$ wild-type background [28, 32].

Then, how do the mutant $\mathrm{Cbl}$ proteins function? Considering the high degree of structural similarity between $\mathrm{Cbl}$ and $\mathrm{Cbl}-\mathrm{b}$ (and given the relatively epithelial-restricted expression of ( Cbl-c), it is conceivable that mutant $\mathrm{Cbl}$ proteins function as a dominant-negative mutant towards Cbl-b (or, as seen in some patients, towards both $\mathrm{Cbl}$ and Cbl-b if aUPD has not occurred) in hematopoietic cells. Phenotypic differences between mice deficient in $\mathrm{Cbl}$ alone or both $\mathrm{Cbl}$ and $\mathrm{Cbl}-\mathrm{b}$ in the hematopoietic compartment are also consistent with the notion that complete loss of $\mathrm{Cbl}$ functions is necessary to promote myeloid malignancy. While bone marrows showed an expansion of the hematopoietic stem/progenitor compartments in both genetic backgrounds, rapidly fatal myeloproliferative disorder with peripheral organ involvement was seen only in $\mathrm{Cbl}, \mathrm{Cblb}$ double-deficient mice but not in $C b l$-null mice even at an advanced age $[15,35,36]$.

Additionally, mutant $\mathrm{Cbl}$ proteins may function as gain-of-function oncogenes. Considering that essentially all leukemia-associated $\mathrm{Cbl}$ mutants possess an intact TKB and C-terminal motifs that mediate interactions with a variety of signaling proteins, it is logical to hypothesize that these E3-defective proteins will be recruited to activated PTKs (via the TKB domain) and that this will lead to the formation of a signaling complex that lacks the negative regulatory function of wild-type $\mathrm{Cbl}$. In this scenario, mutant $\mathrm{Cbl}$ proteins will associate more persistently with signaling intermediates through phosphotyrosine-containing motifs, proline-rich regions and other potential motifs. Thus, mutant $\mathrm{Cbl}$ proteins are likely to serve as supramolecular scaffolds to assemble aberrant signaling complexes that can promote hyperactivation of signaling pathways normally attenuated by E3-competent wild-type Cbl. This idea is compatible with more robust transforming ability of $70 \mathrm{Z} \mathrm{Cbl} \mathrm{compared} \mathrm{to} \mathrm{v}$-Cbl-equivalent sequences when expressed in fibroblasts [20] and a stronger biochemical activation of PDGFR signaling cascade by $70 \mathrm{Z} \mathrm{Cbl}$ and other full-length $\mathrm{Cbl}$ mutants compared to v-Cbl [37].

Further support for this idea comes from analyses of a mutant $\mathrm{Cbl}$ knock-in mouse model developed by Langdon and colleagues in which a Cbl RING finger mutant (C379A, equivalent to C381 in human) is expressed from the endogenous $\mathrm{Cbl}$ promoter [38]. While homozygous mutant mice show early lethality, heterozygous mutant mice with one wild-type $\mathrm{Cbl}$ allele do not show hematopoietic abnormalities. However, mice with one C379A mutant allele on a $\mathrm{Cbl}$-null background (with wild-type $\mathrm{Cblb}$ ) succumb to myeloid malignancies with a median survival time of 47 weeks [36]; although the disease in these mice develops later than in $\mathrm{Cbl}, \mathrm{Cblb}$ double-deficient mice [35], the overall features of the disease are remarkably similar. Interestingly, Akt was constitutively activated in the C379A mutant hematopoietic cells but not in control or $\mathrm{Cbl}$-null mutant cells [36]. This was accompanied by the enhanced phosphorylation of Y737 (corresponding to Y731 in human) of $\mathrm{Cbl}$, an experimentally-proven binding site for the $\mathrm{p} 85$ regulatory subunit of PI3K. These findings in an in vivo model that phenocopies critical features of human diseases support the premise that an E3-deficient oncogenic Cbl mutant is capable of hyperactivating a key pathway through an associated signaling partner whose function would have been attenuated by wild-type Cbl. Thus, it will be highly pertinent in future studies to use this and other mouse models to identify and evaluate 
the activation status of PTKs that serve as physiological targets of $\mathrm{Cbl}$ proteins in hematopoietic stem cells, and to assess which signaling pathways are rendered hyperactive as a result of the expression of a gain-of-function $\mathrm{Cbl}$ mutant. Clearly, to distinguish between the dominantnegative and gain-of-function mechanisms of mutant Cbl-dependent oncogenesis, it is imperative to test their activities in cellular environments completely free of endogenous $\mathrm{Cbl}$ proteins. $\mathrm{Cbl}, \mathrm{Cblb}$ double-deficient mice [35] as well as cells derived from these animals should be valuable research tools for this purpose.

Considering Cbl's interaction with various signaling molecules, mutant $\mathrm{Cbl}$ is likely to affect a multitude of downstream pathways. We discussed the constitutive activation of the Akt-PI3K pathway above [36]. Because $C B L$ mutations are seen in a sizable fraction of JMML cases, a disease entity strongly linked to hyperactivation of the Ras-Raf-MAPK pathway [34], activity of this pathway needs to be carefully evaluated. Indeed, Erk activation of

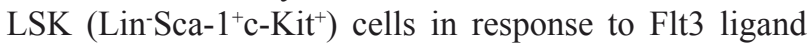
stimulation is prolonged in C379A mice [36], suggesting that this is another potential pathway affected by $C B L$ mutation. Molecular basis of Cbl-mediated regulation of the MAPK pathway has been proposed previously [6]. Furthermore, mutant $\mathrm{Cbl}$ proteins may also influence cytoskeletal reorganization and cell motility through their interaction with the Rac1 and Cdc42 pathways [39, 40]. Comprehensive structure-function analyses using ectopic expression of mutant $\mathrm{Cbl}$ proteins in hematopoietic stem cells and, in the long run, from its endogenous promoter through knock-in approaches should help directly test these potential mechanisms in leukemogenesis and disease progression. Finally, aberrations of other pathways such as RUNX1,JAK2, and FLT3 are found in human patients with $C B L$ mutations [28, 41, 42]. Therefore, modeling these additional oncogenic events in cellular and animal models should help provide a fuller picture of mutant $\mathrm{Cbl}-$ driven leukemogenic process.

Importantly, many of the signaling pathways that appear to be linked to mutant Cbl-driven oncogenesis are also known to be hyperactive in other cancer, and are currently being pursued actively as potential therapeutic targets. Therefore, a better understanding of the spectrum of signaling alterations provoked by mutant $\mathrm{Cbl}$ proteins is likely to reveal logical therapeutic strategies for patients with $C B L$ mutations. Because mutant $\mathrm{Cbl}$ proteins may unleash pathways that are distinct from those engaged by its normal counterpart, unbiased genomic and proteomic approaches may help identify potential therapeutic targets. Finally, it may be possible to develop therapeutics that directly target mutant Cbl. Existing biochemical data indicate that mutant $\mathrm{Cbl}$ proteins need to interact with their PTK targets through the TKB domain to exert their transforming activity. Therefore, it is conceivable that interruption of this interaction can block mutant Cbl-driven oncogenesis. While not as widely pursued as inhibitors that target specific catalytically active sites in enzymes (such as protein tyrosine kinases), successful development of small molecule inhibitors of proteinprotein interaction has begun to emerge, validating it as a practical approach [43]. The interaction interfaces that mediate the $\mathrm{Cbl}$ TKB domain binding to cognate phospho-peptide motifs on target PTKs have been structurally characterized and should be useful for a peptidomimetic approach to design small molecule inhibitors. This approach can be complemented with more unbiased chemical library screens. Our laboratories have established high throughput assays that are suitable for screening small molecules as well as for characterization of rationally-designed inhibitors of $\mathrm{Cbl}$ interaction with PTKs [44].

In conclusion, recent identification of mutations of $\mathrm{Cbl}$ in MDS/MPN and development of models that recapitulate features of these diseases in mice have opened exciting new avenues to translate what we have learned over the last two decades about the multi-faceted roles of $\mathrm{Cbl}$ family proteins as negative regulators of PTK signaling. These new findings also pose new questions about the functional roles of $\mathrm{Cbl}$ proteins, mechanisms by which these proteins regulate hematopoietic (and potentially other) stem cell programs, and how these new findings can be channeled into new diagnostic and therapeutic opportunities.

\section{ACKNOWLEDGEMENTS}

Work in the authors' laboratories was supported by grants from the US National Institutes of Health (CA87986, CA99163, CA105489 and CA116552 to H.B.; CA96844 to V.B.; CA127239 to A.N.; CA134660 to M.S.), the US Department of Defense Breast Cancer Research Program (W81XWH-11-1-0166 to H.B; W81XWH-07-1-0351 and W81XWH-11-1-0171 to V.B; W81XWH-10-1-0740 to M.N.), University of Nebraska Medical Center (UNMC)-Eppley Cancer Center (Pilot Grants to M.N. and V.B.), Nebraska Department of Health and Human Services (LB-506 grant to S.M.R.) and Nebraska Center for Nanomedicine-Center for Biomedical Research Excellence (NCN-COBRE; seed grant to S.M.R.).

\section{REFERENCES}

1. Cancer Facts \& Figures 2010. 2010; Available from: http://www.cancer.org/acs/groups/content/@ epidemiologysurveilance/documents/document/ acspc-026238.pdf

2. Lapidot T, Sirard C, Vormoor J, Murdoch B, Hoang T, Caceres-Cortes J, Minden M, Paterson B, Caligiuri MA, Dick JE. A cell initiating human acute myeloid leukaemia after transplantation into SCID mice. Nature. 1994; 367: 645-648. 
3. Druker BJ, Talpaz M, Resta DJ, Peng B, Buchdunger E, Ford JM, Lydon NB, Kantarjian H, Capdeville R, OhnoJones S, Sawyers CL. Efficacy and safety of a specific inhibitor of the BCR-ABL tyrosine kinase in chronic myeloid leukemia. N Engl J Med. 2001; 344: 1031-1037.

4. Thien CB, Langdon WY. Cbl: many adaptations to regulate protein tyrosine kinases. Nat Rev Mol Cell Biol. 2001; 2: 294-307.

5. Duan L, Reddi AL, Ghosh A, Dimri M, Band H. The Cbl family and other ubiquitin ligases: destructive forces in control of antigen receptor signaling. Immunity. 2004; 21 : 7-17.

6. Schmidt $\mathrm{MHH}$, Dikic I. The Cbl interactome and its functions. Nat Rev Mol Cell Biol. 2005; 6: 907-918.

7. Lupher ML, Rao N, Eck MJ, Band H. The Cbl protooncoprotein: a negative regulator of immune receptor signal transduction. Immunol Today. 1999; 20: 375-382.

8. Joazeiro CA, Wing SS, Huang H, Leverson JD, Hunter $\mathrm{T}$, Liu YC. The tyrosine kinase negative regulator $\mathrm{c}-\mathrm{Cbl}$ as a RING-type, E2-dependent ubiquitin-protein ligase. Science. 1999; 286: 309-312.

9. Levkowitz G, Waterman H, Ettenberg SA, Katz M, Tsygankov AY, Alroy I, Lavi S, Iwai K, Reiss Y, Ciechanover A, Lipkowitz S, Yarden Y. Ubiquitin ligase activity and tyrosine phosphorylation underlie suppression of growth factor signaling by c-Cbl/Sli-1. Mol Cell. 1999; 4: 1029-1040.

10. Yokouchi M, Kondo T, Houghton A, Bartkiewicz M, Horne WC, Zhang H, Yoshimura A, Baron R. Ligandinduced ubiquitination of the epidermal growth factor receptor involves the interaction of the c-Cbl RING finger and UbcH7. J Biol Chem. 1999; 274: 31707-31712.

11. Meng W, Sawasdikosol S, Burakoff SJ, Eck MJ. Structure of the amino-terminal domain of Cbl complexed to its binding site on ZAP-70 kinase. Nature. 1999; 398: 84-90.

12. Zheng N, Wang P, Jeffrey PD, Pavletich NP. Structure of a c-Cbl-UbcH7 complex: RING domain function in ubiquitin-protein ligases. Cell. 2000; 102: 533-539.

13. Murphy MA, Schnall RG, Venter DJ, Barnett L, Bertoncello I, Thien CB, Langdon WY, Bowtell DD. Tissue hyperplasia and enhanced T-cell signalling via ZAP-70 in c-Cbldeficient mice. Mol Cell Biol. 1998; 18: 4872-4882.

14. Naramura $\mathrm{M}$, Kole $\mathrm{HK}, \mathrm{Hu} \mathrm{RJ}, \mathrm{Gu} \mathrm{H}$. Altered thymic positive selection and intracellular signals in Cbl-deficient mice. Proc Natl Acad Sci USA. 1998; 95: 15547-15552.

15. Rathinam $\mathrm{C}$, Thien CBF, Langdon WY, Gu H, Flavell RA. The E3 ubiquitin ligase c-Cbl restricts development and functions of hematopoietic stem cells. Genes Dev. 2008; 22: 992-997.

16. Bachmaier K, Krawczyk C, Kozieradzki I, Kong YY, Sasaki T, Oliveira-dos-Santos A, Mariathasan S, Bouchard D, Wakeham A, Itie A, Le J, Ohashi PS, Sarosi I, Nishina H, Lipkowitz S, Penninger JM. Negative regulation of lymphocyte activation and autoimmunity by the molecular adaptor Cbl-b. Nature. 2000; 403: 211-216.

17. Chiang YJ, Kole HK, Brown K, Naramura M, Fukuhara S, Hu RJ, Jang IK, Gutkind JS, Shevach E, Gu H. Cbl-b regulates the $\mathrm{CD} 28$ dependence of T-cell activation. Nature. 2000; 403: 216-220.

18. Naramura M, Jang I, Kole H, Huang F, Haines D, Gu $\mathrm{H}$. c-Cbl and Cbl-b regulate $\mathrm{T}$ cell responsiveness by promoting ligand-induced TCR down-modulation. Nat Immunol. 2002; 3: 1192-1199.

19. Blake TJ, Heath KG, Langdon WY. The truncation that generated the v-cbl oncogene reveals an ability for nuclear transport, DNA binding and acute transformation. EMBO J. 1993; 12: 2017-2026.

20. Andoniou CE, Thien CB, Langdon WY. Tumour induction by activated abl involves tyrosine phosphorylation of the product of the cbl oncogene. EMBO J. 1994; 13: 45154523.

21. Sargin B, Choudhary C, Crosetto N, Schmidt MHH, Grundler R, Rensinghoff M, Thiessen C, Tickenbrock L, Schwäble J, Brandts C, August B, Koschmieder S, Bandi SR, Duyster J, Berdel WE, Müller-Tidow C, et al. Flt3dependent transformation by inactivating $\mathrm{c}-\mathrm{Cbl}$ mutations in AML. Blood. 2007; 110: 1004-1012.

22. Caligiuri MA, Briesewitz R, Yu J, Wang L, Wei M, Arnoczky KJ, Marburger TB, Wen J, Perrotti D, Bloomfield CD, Whitman SP. Novel c-CBL and CBL-b ubiquitin ligase mutations in human acute myeloid leukemia. Blood. 2007; 110: 1022-1024.

23. Abbas S, Rotmans G, Löwenberg B, Valk PJM. Exon 8 splice site mutations in the gene encoding the E3-ligase CBL are associated with core binding factor acute myeloid leukemias. Haematologica. 2008; 93: 1595-1597.

24. Dunbar AJ, Gondek LP, O'Keefe CL, Makishima H, Rataul MS, Szpurka H, Sekeres MA, Wang XF, McDevitt MA, Maciejewski JP. 250K single nucleotide polymorphism array karyotyping identifies acquired uniparental disomy and homozygous mutations, including novel missense substitutions of c-Cbl, in myeloid malignancies. Cancer Res. 2008; 68: 10349-10357.

25. Reindl C, Quentmeier H, Petropoulos K, Greif PA, Benthaus T, Argiropoulos B, Mellert G, Vempati S, Duyster J, Buske C, Bohlander SK, Humphries KR, Hiddemann W, Spiekermann K. CBL exon 8/9 mutants activate the FLT3 pathway and cluster in core binding factor/11q deletion acute myeloid leukemia/myelodysplastic syndrome subtypes. Clin Cancer Res. 2009; 15: 2238-2247.

26. Grand FH, Hidalgo-Curtis CE, Ernst T, Zoi K, Zoi C, McGuire C, Kreil S, Jones A, Score J, Metzgeroth G, Oscier D, Hall A, Brandts C, Serve H, Reiter A, Chase AJ, et al. Frequent $\mathrm{CBL}$ mutations associated with 11q acquired uniparental disomy in myeloproliferative neoplasms. Blood. 2009; 113: 6182-6192.

27. Loh ML, Sakai DS, Flotho C, Kang M, Fliegauf M, Archambeault S, Mullighan CG, Chen L, Bergstraesser E, 
Bueso-Ramos CE, Emanuel PD, Hasle H, Issa J, van den Heuvel-Eibrink MM, Locatelli F, Stary J, et al. Mutations in CBL occur frequently in juvenile myelomonocytic leukemia. Blood. 2009; 114: 1859-1863.

28. Sanada M, Suzuki T, Shih L, Otsu M, Kato M, Yamazaki S, Tamura A, Honda H, Sakata-Yanagimoto M, Kumano K, Oda H, Yamagata T, Takita J, Gotoh N, Nakazaki K, Kawamata N, et al. Gain-of-function of mutated C-CBL tumour suppressor in myeloid neoplasms. Nature. 2009; 460: 904-908.

29. Makishima H, Cazzolli H, Szpurka H, Dunbar A, Tiu R, Huh J, Muramatsu H, O'Keefe C, Hsi E, Paquette RL, Kojima S, List AF, Sekeres MA, McDevitt MA, Maciejewski JP. Mutations of e3 ubiquitin ligase cbl family members constitute a novel common pathogenic lesion in myeloid malignancies. J Clin Oncol. 2009; 27: 6109-6116.

30. Muramatsu H, Makishima H, Jankowska AM, Cazzolli H, O'Keefe C, Yoshida N, Xu Y, Nishio N, Hama A, Yagasaki H, Takahashi Y, Kato K, Manabe A, Kojima $\mathrm{S}$, Maciejewski JP. Mutations of an E3 ubiquitin ligase c-Cbl but not TET2 mutations are pathogenic in juvenile myelomonocytic leukemia. Blood. 2010; 115: 1969-1975.

31. Fernandes MS, Reddy MM, Croteau NJ, Walz C, Weisbach H, Podar K, Band H, Carroll M, Reiter A, Larson RA, Salgia R, Griffin JD, Sattler M. Novel oncogenic mutations of $\mathrm{CBL}$ in human acute myeloid leukemia that activate growth and survival pathways depend on increased metabolism. J Biol Chem. 2010; 285: 32596-605

32. Niemeyer CM, Kang MW, Shin DH, Furlan I, Erlacher M, Bunin NJ, Bunda S, Finklestein JZ, Sakamoto KM, Gorr TA, Mehta P, Schmid I, Kropshofer G, Corbacioglu $\mathrm{S}$, Lang PJ, Klein C, et al. Germline CBL mutations cause developmental abnormalities and predispose to juvenile myelomonocytic leukemia. Nat Genet. 2010; 42: 794-800.

33. Schubbert S, Shannon K, Bollag G. Hyperactive Ras in developmental disorders and cancer. Nat Rev Cancer. 2007; 7: 295-308.

34. Emanuel PD. Juvenile myelomonocytic leukemia and chronic myelomonocytic leukemia. Leukemia. 2008; 22: 1335-1342.

35. Naramura M, Nandwani N, Gu H, Band V, Band H. Rapidly fatal myeloproliferative disorders in mice with deletion of Casitas B-cell lymphoma (Cbl) and Cbl-b in hematopoietic stem cells. Proc Natl Acad Sci USA. 2010; 107: 1627416279 .

36. Rathinam C, Thien CBF, Flavell RA, Langdon WY. Myeloid leukemia development in c-Cbl RING finger mutant mice is dependent on FLT3 signaling. Cancer Cell. 2010; 18: 341-352.

37. Bonita DP, Miyake S, Lupher ML, Langdon WY, Band H. Phosphotyrosine binding domain-dependent upregulation of the platelet-derived growth factor receptor alpha signaling cascade by transforming mutants of $\mathrm{Cbl}$ : implications for Cbl's function and oncogenicity. Mol Cell Biol. 1997; 17: 4597-4610.
38. Thien CBF, Blystad FD, Zhan Y, Lew AM, Voigt V, Andoniou CE, Langdon WY. Loss of c-Cbl RING finger function results in high-intensity TCR signaling and thymic deletion. EMBO J. 2005; 24: 3807-3819.

39. Wu WJ, Tu S, Cerione RA. Activated Cdc42 sequesters c-Cbl and prevents EGF receptor degradation. Cell. 2003; 114: 715-725.

40. Duan L, Raja SM, Chen G, Virmani S, Williams SH, Clubb RJ, Mukhopadhyay C, Rainey MA, Ying G, Dimri M, Chen J, Reddi AL, Naramura M, Band V, Band H. Negative regulation of EGFR-Vav2 signaling axis by $\mathrm{Cb} 1$ ubiquitin ligase controls EGF receptor-mediated epithelial cell adherens junction dynamics and cell migration. J Biol Chem. 2011; 286: 620-633.

41. Pérez B, Kosmider O, Cassinat B, Renneville A, Lachenaud J, Kaltenbach S, Bertrand Y, Baruchel A, Chomienne C, Fontenay M, Preudhomme C, Cavé H. Genetic typing of CBL, ASXL1, RUNX1, TET2 and JAK2 in juvenile myelomonocytic leukaemia reveals a genetic profile distinct from chronic myelomonocytic leukaemia. Br J Haematol. 2010; 151:460-8.

42. Makishima H, Jankowska AM, McDevitt MA, O'Keefe C, Dujardin S, Cazzolli H, Przychodzen B, Prince C, Nicoll J, Siddaiah H, Shaik M, Szpurka H, Hsi E, Advani A, Paquette R, Maciejewski JP. CBL, CBLB, TET2, ASXL1, and IDH1/2 mutations and additional chromosomal aberrations constitute molecular events in chronic myelogenous leukemia. Blood. 2011 Feb 23. [Epub ahead of print]

43. Azmi AS, Mohammad RM. Non-peptidic small molecule inhibitors against Bcl-2 for cancer therapy. J Cell Physiol. 2009; 218: 13-21.

44. Kumar EA, Charvet CD, Lokesh GL, Natarajan A. Highthroughput fluorescence polarization assay to identify inhibitors of casitas B-lineage lymphoma(tyrosine kinase binding)-protein tyrosine kinase interactions. Anal Biochem. 2010 Dec 1. [Epub ahead of print] 